\author{
Галина Кобиринка \\ Інститут української мови НАН України \\ Київ \\ ORCID: 0000-0001-6615-4924; e-mail: Kobyrynka2008@ukr.net
}

\title{
Атлас украӥнської мови як джерело дослідження української діалектної акцентної системи
}

\begin{abstract}
Реферат: У студії звернено увагу на джерела дослідження української діалектної акцентної системи, зокрема докладніше проаналізовано загальномовний «Атлас української мови». 3'ясовано, що межі поширення акцентуаційних рис представлено на різнотипних картах: регіональних, які відбивають протиставлення акцентуаційних явищ у межах окремих зон; ізоглосних, на яких лініями окреслено межі поширення акцентних одиниць; синтетичній, комплексній, чи так званій зведеній, методом побудови якої є рекартографування - акцентуаційні риси проаналізовано на всьому українському діалектному континуумі. Окрім карт, присвячених акцентній системі української мови, наголошення в «Атласі української мови» зображено також як супровідну рису на фонетичних, морфологічних, лексичних картах. Визначено, що об'єктом картографування були іменники, прикметники, числівники, займенники та їх граматичні форми; описано ареали функціонування акцентуаційних рис, явищ, які проілюстровані на картах АУМ. Виявлено, що чимало інформації зберігають некартографовані матеріали. Водночас зазначено риси, тенденції, особливості наголошення, про які сигналізують карти АУМ. Зауважено, що АУМ також $є$ надійним джерелом у вивченні явища інтерференції на акцентному рівні; виявленні діалектної основи літературно-нормативного наголошення.

Зроблено висновок, що саме за допомогою лінгвогеографічного методу дослідник має змогу отримати новий цінний і переконливий матеріал, який уможливлює не лише окреслити ареали функціонування певного явища, а й доповнити наукові положення, уточнити, змінити чи й зовсім заперечити їх.
\end{abstract}

Ключові слова: діалект, наголошення, акцентна система, лінгвістичний атлас, карти, ареали мовного явища.

Abstract: Atlas of the Ukrainian language as a source of research into the Ukrainian dialectal accent system. The study focuses on the sources of research into the Ukrainian dialectal accent system with special emphasis placed on a detailed comprehensive analysis of the "Atlas of the Ukrainian language». It has been established that the definition of the bound areas of distribution of the accentuation feature sis represented by different types of maps: regional, reflecting the contrast of the accentuation phenomena within several zones; isoglottic, outlining the boundaries of the distribution of the accent units; synthetic, complex, or the so-called consolidated. By means of re-cartography, a constructing method, the accentuation features are outlined throughout the Ukrainian dialect continuum. Beside the maps devoted to the accent system of the Ukrainian language, the accent in the "Atlas of the Ukrainian language» is also depicted as an accompanying feature on phonetic, morphological and lexical maps. It was determined that the object of cartography were nouns, adjectives, numerals, pronouns and their grammatical forms. The article presents the functioning of the accentuation features, phenomena, illustrated on the maps of the «Atlas of the Ukrainian language». It has been found out that lots of informa- 
tion is stored in non-cartographic material. At the same time, there are features, tendencies and idiosyncrasies of the accentuation as indicated on the maps of the "Atlas of the Ukrainian language». It has been noted that the «Atlas of the Ukrainian language» is also a reliable source of studies of the interference phenomena at the accent level and the search of the dialectal basis of literary and normative accentuation.

A conclusion has been drawn that by means of the linguo-geographic method, a researcher is able to obtain new, valuable and convincing material that enables not only to outline the areas of a specific phenomenon, but also to supplement the scientific positions, clarify, change or completely deny them.

Keywords: dialect, accentuation, accent system, linguistic atlas, maps, areas of speech phenomenon.

Кінець XX - початок XXI ст. позначений особливою увагою до говіркового мовлення. Сьогодні дослідження українських діалектів у синхронному та діахронному аспектах мають значні здобутки. Науковці здійснюють типологічний аналіз діалектів, окреслюють межі поширення структурних одиниць, вивчають структурно-семантичні відношення, просторову варіативність, міжслов’янські зв'язки.

Важливе значення має, вибір гносеологічної оптики - докладний аналіз окремих структурних елементів / явищ / процесів (відповідно до визначеної мети) чи загальна характеристика говірки, діалекту; застосування дескрипційної методики чи використання спеціальних прийомів пізнання (моделювання, статистичного і трансформаційного аналізу тощо) (Гриценко 2017, 9-10).

В українському діалектному просторі докладного системного вивчення потребує акцентна система. Сьогодні очевидними є загальні відомості про український діалектний наголос, зокрема: фонологічне розрізнення наголошених і ненаголошених складів у говірках, експіраторну силу українського наголосу, синтагматичну акцентуацію (О. Брох, С. Смаль-Стоцький, Т. Лер-Сплавінський, Я. Янов, М. Дурново, I. Зілинський, В.М. Брахнов, О. Курило, О.С. Біла, Т.В. Назарова, Л.М. Коць-Григорчук); рухомість і різномісність наголосу в українських говірках (бойківських - I. Свєнціцький, С. Рабій-Карпинська, Г.С. Кобиринка; наддністрянських - I. Верхратський, Д.Г. Гринчишин, К. Дейна [зокрема українські говірки Тернопільщини]; говірках Західної Дрогобиччини - Я.О. Пура; надсянських - Я. Рігер; гуцульських - Б. Кобилянський; перехідної гуцульсько-покутської говірки с. Саджава Івано-Франківської обл. - Г.П. Клепікова; українських карпатських говірок на схід від Ослави і Лаборця - W. Lukasik-Szulowska; південнолемківської говірки села Красний Брід бл. Меджилаборець (Пряшівщина) - О. Горбач; говірок околиці Ужгорода - П.П. Чучка; марамороської говірки с. Вишня Рона О. Ковач; українських говірок Східної Словаччини - В. Латта; говірки с. Авратин Волочиського р-ну Хмельницької обл. - П.Є. Ткачук; говірок Уманського району на Черкащині, які належать до перехідних говірок від південно-східних до південно-західних - А.Д. Очеретний; середньонаддніпрянських, зокрема говірок с. Шевченкового і с. Будища Звенигородського р-ну Черкаської обл., - I.Ф. Омельяненко; говірки с. Блиставиці Гостомельського району на Київщині - П.Д. Гладкий; середньополіських, зокрема на теренах Житомирської обл. - В.В. Власенко); акцентуаційні особливості говорів, картографованих (в АУМ, т. 1: Полісся, 
Середня Наддніпрянщина й суміжні землі, I.О. Варченко); парокситонного наголошення в українських говірках (I. Панькевич, 3. Штібер, К. Дейна, Я. Рігер, Л.М. Коць-Григорчук, Г.С. Кобиринка), важливими питаннями залишається вияв наголошення, характер його в словах різних граматичних класів, ступінь оформленості акцентних типів, їх ареалогія тощо.

Для реалізації системного вивчення українського діалектного наголосу передусім необхідно зафіксувати говірковий матеріал; відповідно до поставлених завдань дібрати джерельну базу, яка забезпечить повноту, достовірність матеріалу, уможливить здійснити його системний аналіз, зробити грунтовні об'єктивні висновки.

Джерелами дослідження української діалектної акцентної системи є:

- відповіді на діалектологічні питальники, анкети (зауважимо, що збирання акцентуаційного матеріалу було передбачено вже на поч. ХХ ст. (Програма 1909, 1910);

- діалектні, а також фольклорні, художні тексти, у яких позначено наголос, і які відтворюють говірку, іiі мовленнєвий образ;

- лексикографічні праці (укладено діалектні словники різних типів, у яких усі слова, крім односкладових, подано з наголосом, нерідко представлено й акцентні варіанти, елементи граматичної характеристики реєстрових слів (здебільшого це форми родового відмінка однини та називного відмінка множини), зафіксовано і розрізнення семантики за допомогою наголосу; акцентуаційна інформація представлена і в розлогих ілюстраціях до вокабул у словниках);

- лінгвогеографічні праці - загальномовний Атлас украӥнської мови (АУМ); регіональні атласи: Atlas gwar bojkowskich за редакцією Я. Рігера (AGB), Lexical Atlas of the Hutsul Dialects of the Ukrainian Language (Rieger 1996), Atlas językowy dawnej Łemkowszczyzny (Stieber 1956-1964), Лінгвістичний атлас українських говорів Східної Словаччини (Ганудель 1984-2001), Атлас украӥнських говорів Східної Словаччини (Латта 1991), Лінгвістичний атлас украӥнських народних говорів Закарпатської області УРСР (ДЛАЗ), Лінгвістичний атлас Нижньої Прип'яті (Назарова 1985) та ін. ${ }^{1}$, а також Карпатський діалектологічний атлас (КДА); інформацію про мовну структуру українських говірок вміщено в Общекарпатском диалектологическом атласе (ОКДА), Общеславянском лингвистическом атласе (ОЛА); на роль лінгвогеографічного методу у вивченні проблеми міжмовних контактів у цілому, й у галузі акцентології зокрема, звертали увагу I. Варченко (1971, 46-59) Л.М. Коць-Григорчук (1997, 304-327; 2002), Е. Смулкова (Smułkowa 2002), які підкреслювали, що свідчення лінгвогеографії можуть допомогти розв'язанню проблеми акцентуаційних міжмовних контактів;

- дескриптивні дослідження (у монографічних, дисертаційних працях та численних студіях представлено об’єктивну картину мовного стану старожитніх та новожитніх говірок);

\footnotetext{
1 Інформацію про діалектні словники, лінгвогеографічні атласи див. на сайті Інституту української мови НАН України: http://www1.nas.gov.ua/institutes/ium/Structure/Departments/Department4/Pages/ atlases.aspx.
} 
- український діалектний фонофонд, який створено у відділі діалектології Інституту української мови НАН України² (Гриценко 2002);

- писемні пам'ятки, у яких зазначено наголос (простежити розвиток української акцентної системи можна тільки з кінця XVI ст., оскільки в цей час у книжках почали ставити наголос (Веселовська 1970); зокрема, систематично наголоси проставлені в стародруках - «Апостол» (Львів, 1574 р.), Острозькій Біблії (1581р.) (Скляренко 1983, 4-5);

- реконструйована праслов'янська акцентна система (це дослідження Л.А. Булаховського, В.Г. Скляренка, В.М. Ілліча-Світича, В.А. Дибо, В.В. Колесова, А.А. Залізняка; ці праці, так само, як і писемні акцентовані пам'ятки, сприяють з'ясуванню генези акцентного типу чи явища в говірці, встановленню динамічних і виявленню архаїчних й інноваційних процесів).

Зазначені джерела містять надійний матеріал для дослідження української діалектної акцентної системи в синхронії та діахронії. Водночас на особливу увагу заслуговує фундаментальна праця українських діалектологів - загальномовний національний Атлас украӥнської мови, на картах якого в ареальній проєкції відбито функціонування територіальних діалектів української мови на різних структурних рівнях мови. Але укладанням лінгвістичних карт не завершується вивчення мовних явищ, а тільки починається, оскільки «лінгвістична карта - це лише підготовлений матеріал, схема, формула, яка потребує розв'язання, дешифрування, прочитання» (Дзендзелівський 1965, 20). Сьогодні актуальним є, як зазначає П.Ю. Гриценко, «з’ясування інформаційних можливостей карт, пошуки відповідей на питання: що дає лінгвістична карта для пізнання мови, історії етносу і в яких аналітичних процедурах це джерело інформації має безсумнівні переваги, а в яких безальтернативне?» (Гриценко 2004, 86).

Отож, постають питання: яку інформацію дають карти АУМ; які елементи, явища були об'єктом картографування на акцентному рівні; які ареали окреслено відповідно до функціонування акцентуаційних рис, явищ, що проілюстровані на картах АУМ? Адже з-поміж завдань АУМ було встановити межі поширення мовних рис; «на фоні рис, спільних для всіх діалектів української мови, простежити якомога повніше і грунтовніше характерні відмінності між українськими говорами» (Програма, 1949, 9). Матеріал до АУМ зібрано із 2359 говірок за єдиною програмою Б.О. Ларіна, яка «відбиває рівень мовознавчих i, зокрема, лінгвогеографічних досліджень того періоду і з сучасного погляду характеризується певними вадами» (АУМ, I, 8), які укладачі карт намагалися виправити. Зокрема, лінгвістичну інформацію атласу розширено картами наголосу, які ілюструють діалектні особливості наголошення слів та окремих іменникових, займенникових, дієслівних парадигм, попри те, що Програма не передбачала жодної карти щодо функціонування акцентуаційних рис, Ф.Т. Жилко, працюючи над укладанням карт до АУМ, зазначав, що «наголошування само по собі для українських говорів такий

2 у фонофонді представлено магнітофонні записи говірок 3 усього українського діалектного континууму - із 900 населених пунктів переважно з теренів України, а також з-поза України: Росії, Білорусі, Польщі, Словаччини, Румунії, Молдови, Югославії. Чимало записів відтворюють мовлення діалектоносіїв, народжених у XIX ст. (найстарші інформант 1874-1876 років народження). 
виразний діалектний елемент, що ми складаємо окремі акцентуаційні карти. Це карти наголосу окремих слів - частин мови або рідше - рядів слів (певних граматичних категорій)» (Жилко 1965, 9).

Окреслення меж поширення акцентуаційних рис в АУМ представлено на різнотипних картах: регіональних, які відбивають протиставлення акцентуаційних явищ у межах окремих зон (т. 1: Полісся, Середня Наддніпрянщина і суміжні землі; т. 2: Волинь, Наддністрянщина, Закарпаття і суміжні землі; т. 3, ч. 1: Донеччина, Слобожанщина і суміжні землі; т. 3, ч. 2: Нижня Наддніпрянщина, Причорномор'я і суміжні землі); ізоглосних - карти ареалів, на яких лініями окреслено межі поширення акцентних одиниць - ізоакценти; системних картах, у яких, за допомогою використання методики накладання ареалів генетично й структурно пов'язаних елементів мови акцентуаційні риси відображено на всьому українському просторі.

Об'єктом картографування в АУМ було наголошення граматичних класів та їх форм, зокрема:

- називного відмінка однини іменників бр'іфташка (АУМ, II к. 297), дрова (АУМ, I, к. 150), жайворонок (АУМ, III-1, к. 27), зор’а, зорна (АУМ, II, к. 116), кои'уба (АУМ, II, к. 282), коч')ерга (АУМ, II, к. 134), мошонка (АУМ, II, к. 297), праник (АУМ, ІІІ-2, к. 37), пул'арес (АУМ, II, к. 297), руно (АУМ, І, к. 147), сміття (АУМ, І, к. 148), труна, трумна, трумла (АУМ, ІІ, к. 134), хворост (АУМ, III-1, к. 28), цебер (АУМ, ІІІ-2, к. 41), щуавель (АУМ, III-1, к. 29);

- називного відмінка множини іменників корова (АУМ, I, к. 151), хустка (АУМ, I, к. 152); долото й парного іменника ворота (АУМ, II, к. 130);

- родового відмінка множини іменника кістка (АУМ, І, к. 153);

- наголошення іменника в словосполученні три брати (АУМ, І, к. 149; III-2, к. 80);

- якісних прикметників чол. р.: рясний (АУМ, I, к. 154), вуз'кий, вохкиц̆, m’icний (АУМ, II, к. 131);

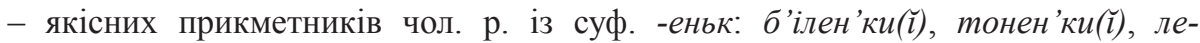
ген'ки(г) (АУМ, I, к. 155; II, к. 131);

- присвійних займенників у формі родового відмінка однини мій, твій (АУМ, I, к. 156; II, к. 132; III-2, к. 38);

- вказівного займенника у формі давального відмінка однини той (АУМ, I, к. 157);

- кількісного числівника у формі родового відмінка однини один (АУМ, I, К. 158);

- порядкового числівника сороковий (АУМ, ІІІ-2, к. 39);

- неозначеної форми дієслів жевріти (АУМ, І, к. 159), литати, тлигати (АУМ, II, к. 383);

- 1-ої особи однини теперішнього часу дієслів II дієвідміни кошу, ношу, прошу і кос'y, нос'y, прос'y (АУМ, II, к. 133);

- форми минулого часу множини дієслова взяти (АУМ, ІІІ-2, к. 40).

Окремі карти присвячено явищу парокситонези - наголошувати другий склад із кінця слова (АУМ, ІІ, к. 134-135). Наголос на пенультимі скартографовано

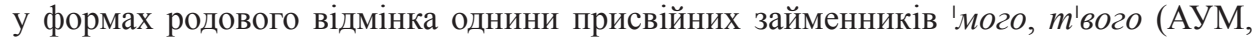


II, к. 134); 1-ої особи однини теперішнього часу дієслів II дієвідміни 'кошу, 'ношу, $n^{\prime}$ рошу і 'кос'y, 'нос'y, n'рос'y (АУМ, II, к. 134, 235); називного відмінка однини окремих іменників ко'ч(')ега, ко'и'уба (АУМ, ІІ, к. 134, 282); m'руна, m'румна, $m^{\prime}$ румла (АУМ, II, к. 134). Парокситонезу проілюстровано й у парадигмі відмінювання деяких іменників 'тел'а, 'тел'ім...; 'лоша, 'лош'ім... (АУМ, II, к. 134, 135).

Ареали виявів парокситонного наголошення граматичних форм іменників, прикметників, числівників, займенників, дієслів засвідчують й інші карти АУМ (головним об'єктом картографування яких були елементи інших структурних рівнів), наприклад: іменників у формі називного відмінка однини 'зор'а, 'зорйа (АУМ, II, к. 116); у формі називного відмінка множини іменника брат - б'pam'i (АУМ, II, к. 191); у формі родового відмінка множини іменника гість - 'гостиц і 'гост 'iy̆ (АУМ, II, к. 198); у формі давального відмінка множини іменника брат - б'рат'ам (АУМ, ІІ, к. 202); дієслів 'литати, тли'тати (АУМ, ІІ, к. 383); прикметників 'вуз'кий, 'вохкий, 'm'існий (АУМ, II, к. 131) та ін.

Очевидним є те, що ядром парокситонного наголошення в українському діалектному просторі $є$ лемківські говірки, яким властива, за визначенням Л.М. Коць-Григорчук, повна (для дво-, три- і більшескладових слів), постійна (у словозмінній парадигмі) парокситонеза, а далі на північ за інтенсивністю це явище поступово згасає $\epsilon^{3}$ (Коць-Григорчук 2002, 53). Карти АУМ засвідчують, що парокситонеза як специфічне явище в наголошенні ${ }^{4}$, яку дослідники на тлі вільного рухомого експіраторного словесного наголосу здебільшого виявляли в говірках південно-західного наріччя, функціонує також в окремих словах і формах у говірках північного, південно-східного наріч, у перехідних говірках від південно-східного до південно-західного наріччя (Варченко 1971, 46-59; Коць-Григорчук 2002; Кобиринка 2012, 121-132).

Підкреслимо, що саме велика зона поширення наголосу на пенультимі в українському мовному просторі дали підстави Л.М. Коць-Григорчук піддати сумнівам визначальну роль польських і словацьких говірок у становленні в лемківських говірках постійного наголосу на другому від кінця слова складі. Дослідниця припускає, що в минулому тенденція наголошувати другий склад від кінця слова існувала «на певній єдиній території на початковій стадії розвитку» і була спільною для чехів, словаків та українців, а «далі ця тенденція по-різному реалізувалася та закріплювалася як явище у західнослов'янських мовах» (Коць-Григорчук 2002, с. 60); на їі думку, парокситонний наголос в українських говірках не запозичине, а власнеукраїнське явище - ставить парокситонне наголошення в українських говірках у рівнорядне становище 3 наголосом словацьких

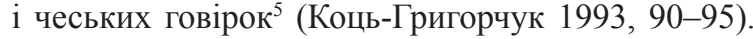

\footnotetext{
3 Докладніше про методи й прийоми дослідження парокситонези див. (Кобиринка 2016, 14-23).
}

${ }^{4}$ На тлі вільного рухомого експіраторного словесного наголосу парокситонезу дослідники сприймають як специфічне явище в наголошенні, оскільки таке наголошення в багатьох словах та їх формах вирізняє говірки 3-поміж інших, є їхнім диференційним маркером в українському просторі, а також відхиленням від літературно-нормативного стандарту.

5 Поширеною $є$ думка, що парокситонний наголос в українських говірках постав унаслідок іншомовних впливів, запозичень, оскільки такий наголос властивий суміжним словацьким говіркам 
Зауважимо, що наголошення в АУМ зображено також як супровідну рису на фонетичних, морфологічних, лексичних картах. Окрім основної, ці карти містять інформацію й щодо наголошення; наприклад, лексичні карти: «Кропива (Urtica L.)» - кропи'ва / кро'пива (АУМ, І, к. 316), «Труна» - тру'на / m'руна (АУМ, I, к. 347); фонетичні: «Відповідники зредукованого голосного (вузол)» - 'вузол / ву'зол (АУМ, І, к. 82); «Відповідники ф (фартух)» фар'mух - 'фартух (АУМ, I, к. 99), «Протетичні [в], [г] перед [у] (вузький)» - вузь'кий / 'вузький (АУМ, І, к. 137), «Рефлекси ненаголошеного Е (рябий) - ря'бий / 'рябий (АУМ, І, к. 50), «1-а особа однини теперішнього часу дієслів II дієвідміни з основою на [д]» - хо'жу / 'хожу (АУМ, III-2, к. 71), «1-а особа однини теперішнього часу дієслів II дієвідміни 3 основою на [c]»- но'шу / 'ношу (АУМ, I, к. 255), «1-а особа множини теперішнього часу дієслів I дієвідміни» - не $e^{(u)} c e^{(u)}$ мо / не $e^{(u)}$ семо, не $e^{(u)}$ сем (АУМ, I, к. 260); морфологічні: «Родовий відмінок іменників гості, гроші, коні» - гос'тец̆, гро'шец̆,

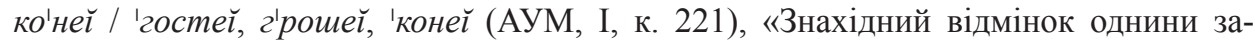
йменника він (з прийменником)» - за 'н'ого' (його, 'йего) / за н'о'го (йо'го, йе'го) (АУМ, І, к. 226); словотвірні: «Морфемна структура іменника ичебер» - 'цебер / цеегер (АУМ, І, к. 162), «Суфікси іменника праник»-n'раник / праник (АУМ, I, к. 171), «Житнище (поле з-під жита)» - 'житнищее / жит'нище (АУМ, I, к. 310); синтаксична карта «Конструція типу у мене болить голова» - y' 'мене / y ме'не (АУМ, I, к. 280) та ін.

Акцентуаційні риси на всьому українському діалектному континуумі відображають комплексні (синтетичні) карти, укладені на основі попередньо скартографованого матеріалу та картотеки некартографованих матеріалів. Зокрема, за матеріалами карт АУМ (I, к. 156-157, 254-255; II, к. 132-135; III-2, к. 38, 69-71) та матеріалами картотеки укладено карти, які відбивають структурні зв'язки між однотипними фрагментами акцентних кривих. Деякі акцентні криві іменних і дієслівних форм проілюстровано за наголосом називного відмінка однини іменника кропи'ва / кро'пива (АУМ, ІІІ-3, к. 51); називного відмінка множини односкладових іменників в’’л, ст'іл, воўк: во'ли, сто'ли, воў'ки / 'воли, с'толи, 'воўки; називного відмінка множини двоскладових іменників із наголосом на першому складі 'холод, 'ворог, 'голос: холо'ди, воро'ги, голо'си / 'холоди, 'вороги, 'голоси; називного відмінка множини двоскладового іменника з наголосом на другому складі $c$ ' $^{\prime} o^{\prime} 3$ : сл'о'за - c'л'оза / c'лиза - сли'зи; називного відмінка однини присвійних займенни-

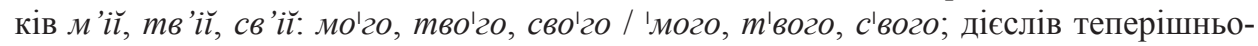
го часу 1 та 2 особи однини но'шу, роб'л'y, хо'з̌y / 'ношу, 'робл'y, 'хоб̆у (АУМ, III-3, к. 22).

Ареали акцентуаційних рис чи явищ ілюструють ізоглосні карти, зокрема:

- північні (поліські) ареали визначено відповідно до наголошення іменника

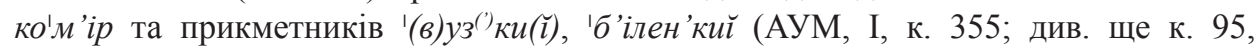
к. 137; II, к. 388-389);

і $є$ визначальним для більшості говірок польського мовного простору (І. Панькевич, Ю. Шевельов, В. Латта, П. Чучка, Я. Пура, 3. Штібер, К. Дейна, Я. Рігер). Водночас існує й інше пояснення цього явища - постання наголосу на пенультимі самостійним шляхом, тобто заперечення іншомовного впливу (І. Огієнко, Л.М. Коць-Григорчук, В.М. Винницький). 
- південно-західні ілюструють іменники пра'ник, цее бер; присвійні займенники у формі родового відмінка однини 'мого, $m^{\prime}$ вого (наголошення цих займенникових форм острівними ареалами заходить аж за р. Тетерів до р-нів Житомирської та Київської областей); дієслова II дієвідміни 1-ї особи однини теперішнього часу 'кошу, 'ношу (АУМ, I, к. 372);

- південно-східні - за наголошенням дієслів I дієвідміни 1-ї особи множини теперішнього часу $н e^{(u) 1}$ семо; ця риса властива також деяким говіркам Житомирської, Київської, Чернігівської областей. (АУМ, І, к. 383);

- східнополтавські - за наголошенням іменника жайворонок (АУМ, III-1, к. 142);

- подільсько-західностепові - на підставі наголошення іменників пра'ник, це'бер; форми родового відмінка однини присвійних займенників 'мого, m'вого; форми минулого часу 3 особи множиниу 'з'али (АУМ, ІІІ-2, к. 146);

- подільсько-наддністрянсько-карпатські - за наголошенням дієслів 1-ї особи однини 'хоз̌у, 'ношу (АУМ, II, к. 397);

- карпатські - за наголошенням іменника ко'черга (АУМ, II, к. 406);

- ареали правобережжя і лівобережжя - відповідно до наголошення іменника ко'рови / коро'ви: правобережна коро'ви, лівобережна - ко'рови (АУМ, І, к. 389; див. також к. 151).

Скартографовані акцентні криві, протиставлені залежно від кінцевого чи некінцевого наголосу (парокситонези, пропарокситонези) іменникових, займенникових, дієслівних словоформ, ілюструють поділ українськомовної території на південно-західний i південно-східний обшири. Вважаємо, що поширення південно-західного типу наголошення на значній території може бути одним із критеріїв олітературнення його як акцентного варіанта ('кажу, 'ношу, 'пишу, 'роблю, 'мого, m'вого, с'вого і под.).

Підкреслимо, що поширення ізоглоси може бути важливим аргументом під час визначення генези говірки. Зокрема, дискусійним питанням у славістиці (між українськими та білоруськими мовознавцями) $є$ генеза берестейсько-пинських говірок: немає однозначної інтерпретації щодо належності цих говірок до української чи до білоруської діалектної території․ Лінгвогеографічні дослідження свідчать, що берестейсько-пинські говірки протиставляються основному білоруському діалектному масиву за наголошенням форми знахідного відмінка одн. іменників жіночого роду з основою на $-a$, ізоглоси яких продовжуються на українськомовній території; у берестейсько-пинських говірках, як і в українських діа-

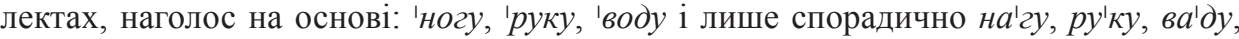
що характерно для говірок білоруської мови, у яких відбулося вирівнювання форми знахідного відмінка однини за наголосом називного відмінка однини,

6 До українських ці говірки відносять українські (К.П. Михальчук, В. Ганцов, О. Курило, I. Зілинський, О. Горбач, Т.В. Назарова, С.П. Бевзенко, Й.О. Дзендзелівський, І.Г. Матвіяс, Г.П. Півторак, Г.Л. Аркушин, О.І. Скопненко та інші), білоруські (Ю.Ф. Карський, М.В. Бірило та інші), польські (Ю. Тарнацький, В. Курашкевич, К. Дейна), російські дослідники (М.М. Дурново, Д.М. Ушаков, Ф.П. Філін); до білоруських - білоруські мовознавці (Я. Станкевич, Н.Т. Войтович, O.I. Чеберук, Ф.Д. Климчук та інші); берестейсько-пинські говірки інтерпретують і як частину діалекту білорусько-ураїнського суміжжя - О.А. Кривицький. 
а в берестейсько-пинських говірках такої закономірності в наголошуванні іменників жіночого роду на - $а$ не зафіксовано (ДАБМ, к. 195). Свого часу Ю.Ф. Карський відзначав, що «випадки акцентування знахідного на корені майже не тра-

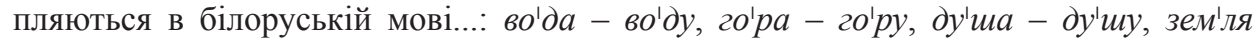
- зем'лю, ко'са - ко'су... й інші» (Карский 1955, 432).

Отже, попри те, що в АУМ, як свідчить наведений вище матеріал, порівняно небагато карт, присвячених наголосові, - 34 (усього карт - 1146), що зумовлено специфікою завдань зібраного матеріалу, ця лінгвогеографічна праця є надійним джерелом для вивчення української акцентної системи в цілому та діалектної зокрема.

Карти АУМ сигналізують про протиставлення українського діалектного простору відповідно до поведінки наголосу в окремих словоформах, рідше - у словозмінній парадигмі; про риси, тенденції, особливості наголошення, передусім це:

- поширення різномісного, рухомого наголосу в українському просторі;

- функціонування парокситонного наголошення іменників, прикметників, числівників, займенників, дієслів на тлі вільного рухомого наголосу в говірках південно-західного, південно-східного, північного наріч;

- функціонування ініціального наголосу прикметників у поліських говірках;

- взаємозв'язок наголосу з іншими структурними рівнями;

- акцентуаційну варіантність;

- явище інтерференції на акцентному рівні;

- діалектну основу літературно-нормативного наголошення (в АУМ колір має інформативне навантаження: червоним кольором на карті позначено варіант, що збігається з літературно-нормативним).

Кожен із зазначених аспектів потребує системного аналізу.

Зрозуміло, що карти АУМ не можуть охопити всієї різноманітності в наголошенні слів, що функціонують у діалектах. Проте окреслені ареали на лінгвістичних картах АУМ, проведені ізоглоси акцентуаційного явища, а також залучення іншого матеріалу (і не тільки лінгвістичного, а й етнографічного, зокрема про національний склад населення, риси матеріальної й духовної культури, історичного - відомості про колонізаційні рухи, переселення тощо) уможливлюють глибше вивчити його природу, з'ясувати процеси утворення, визначити тенденції, ядро і периферію, вивчити інтерферентні процеси, а також генезу говору в цілому та акцентуаційного явища зокрема.

За допомогою лінгвогеографічного методу дослідник має змогу отримати новий цінний і переконливий матеріал, який дає змогу не лише окреслити ареали функціонування певного явища, а й доповнити наукові положення, уточнити, змінити чи й зовсім заперечити їх.

7 Зокрема, Л.М. Коць-Григорчук засобами лінгвогеографії виявила динаміку творення в діалектному просторі явищ i тенденцій синтагматичної акцентуації, фонології i морфології. Взаємопов'язаність акцентуаційних, фонологічних і морфологічних явищ проілюстровано процесом визначення ареалу реліктової флексії -ий родового відмінка множини іменників колишніх ц̆-основ (Коць-Григорчук 2002, 61-69). 


\section{Література}

АУМ, Атлас украӥнської мови у 3 m., [Atlas ukrainskoi movy и 3 t.], т. 1: Полісся, Середня Наддніпрянщина і суміжні землі [Polissia, Serednia Naddniprianshchyna i sumizhni zemli], т. 2: Волинь, Наддністрянщина, Закарпаття і суміжні землі [Volyn, Naddnistrianshchyna, Zakarpattia i sumizhni zemli], т. 3, ч. 1: Донеччина, Слобожанщина і суміжні землі [Donechchyna, Slobozhanshchyna i sumizhni zemli], т. 3, ч. 2: Нижня Наддніпрянщина, Причорномор'я і суміжні землі [Nyzhnia Naddniprianshchyna, Prychornomoria i sumizhni zemli], Київ 1984-2001.

Варченко I.O. [Varchenko I.O.] (1971), Міжмовні акцентуаційні контакти і лінгвогеографія [Mizhmovni aktsentuatsiini kontakty i linhvoheohrafiia], [в:] Праиі ХII Республіканської діалектологічної наради, Київ, с. 46-59.

Веселовська 3.M. [Veselovska Z.M.] (1970), Наголос у східнослов'янських мовах початкової доби формування російської, української та білоруської націй (кінець XVI - початок XVIII століть) [Naholos u skhidnoslov'ianskykh movakh pochatkovoi doby formuvannia rosiiskoi, ukrainskoi ta biloruskoi natsii (kinets XVI - pochatok XVIII stolit)], Київ.

Ганудель 3., [Hanudel Z.] (1984-2001), Лінгвістичний атлас украӥнських говорів Східноі Словаччини [Linhvistychnyi atlas ukrainskykh hovoriv Skhidnoi Slovachchyny], т. I-III, Prešov.

Гриценко П.Ю. [Hrytsenko P.Yu.] (2017), Динаміка діалектного континууму: гносеологічні параметри (вступні зауваги) [Dynamika dialektnoho kontynuити: hnoseolohichni parametry (vstupni zauvahy)], [в:] Діалекти в синхронії та діахронії: трансформація діалектного континууму і проблеми лінгвоекології, Київ, с. 7-13.

Гриценко П.Ю. [Gritsenko P.Yu.] (2004), Об интерпретации лингвистических карт [Ob interpretatsii lingvisticheskih kart], [в:] Общеславянский лингвистический атлас. Мaтериалы и исследования. Сборник научных трудов, 2001-2002, Москва, с. 86-101.

Гриценко П.Ю., Малахівська О.А., Поістогова М.В. [Hrytsenko P.Yu., Malakhivska O.А., Poistohova M.V.] (2004), Український діалектний фонофонд [Ukrainskyi dialektnyi fonofond], Київ.

Дзендзелівський Й.О. [Dzendzelivskyi Y.O.] (1965), Деякі питання методики і теорії інтерпретації лінгвістичних карт (На матеріалах слов'янських атласів) [Deiaki pytannia metodyky i teorii interpretatsii linhvistychnykh kart (Na materialakh slovianskykh atlasiv)], [в:] Праці ХІ республіканської діалектологічної наради, Київ, с. 20-39.

ДЛАЗ, Дзендзелівський Й.О. [Dzendzelivskyi Y.O.], Лінгвістичний атлас українських народних говорів Закарпатської області УРСР [Linhvistychnyi atlas ukrainskykh narodnykh hovoriv Zakarpatskoi oblasti URSR], ч. 1-3, Ужгород, 1958-1993.

Жилко Ф.Т. [Zhylko F.T.] (1965), Основні принципи побудови атласу української мови [Osnovni pryntsypy pobudovy atlasu ukrainskoi movy], [в:] Праціi XI республіканської діалектологічної наради, Київ, с. 3-19.

Карский Е.Ф. [Karskij Е.F.] (1955), Белорусы [Belorusy], вып. I, Москва.

КДА, Бернштейн С.Б., Иллич-Свитыч В.М., Клепикова Г.П., Попова Т.В., Усачева В.В. [Bernshtejn S.B., Illich-Svitych V.M., Klepikova G.P., Popova T.V., Usacheva V.V.] (1967), Карпатский диалектологический атлас [Karpatskij dialektologicheskij atlas] т. 1-2, Moсква.

Кобиринка Г.С. [Kobyrynka H.S.] (2012), Проблеми дослідження парокситонного наголосу в украӥнських говірках [Problemy doslidzhennia paroksytonnoho naholosu $v$ ukrainskykh 
hovirkakh], [в:] Акиентологія. Етимологія. Семантика. До 75-річчя академіка НАН України В.Г. Скляренка, Київ, с. 121-132.

Кобиринка Г.С. [Kobyrynka H.S.] (2016), Прийоми й методи аналізу парокситонези на тлі вільного рухомого наголосу [Pryiomy y metody analizu paroksytonezy na tli vilnoho rukhomoho naholosu], «Українська мова», № 2, с. 14-23.

Коць-Григорчук Л.М. [Kots-Hryhorchuk L.M.] (1993), Украӥнський діалектний парокситонічний наголос [Ukrainskyi dialektnyi paroksytonichnyi naholos], [в:] Другий міжнародний конгрес украӥністів, Львів, с. 90-95.

Коць-Григорчук Л.М. [Kots-Hryhorchuk L.M.] (1997), Лінгвогеографічний аспект української синтагматичної акиентуаиіï [Linhvoheohrafichnyi aspekt ukrainskoi syntahmatychnoi aktsentuatsii], 3НТШ, т. CCXXXIV, с. 304-327.

Коць-Григорчук Л. [Kots-Hryhorchuk L.] (2002), Лінгвістично-географічне дослідження украӥнського діялектного простору [Linhvistychno-heohrafichne doslidzhennia ukrainskoho diialektnoho prostoru], Нью-Йорк - Львів.

Латта B. [Latta V.] (1991), Атлас українських говорів Східної Словаччини [Atlas ukrainskykh hovoriv Skhidnoi Slovachchyny], Братислава.

Назарова Т.В. [Nazarova T.V.] (1985), Лінгвістичний атлас Нижньої Прип'яті [Linhvistychnyi atlas Nyzhnoi Prypiati], Київ.

ОКДА, Общекарпатский диалектологический атлас [Obshhekarpatskij dialektologicheskij atlas], вып. I-VII, Скопје - Кишинев - Москва - Warszawa - Львів - Bratislava Budapest - Белград - Нови сад - Kraków 1987-2012.

ОЛА, Общеславянский лингвистический атлас. Серия фонетико-грамматическая [Obshheslavyanskij lingvisticheskij atlas. Seriya fonetiko-grammaticheskaya], вып. I-VI, Белград - Москва - Wrocław - Warszawa - Kraków - Загреб - Скопје 1988-2006; Серия лексико-словообразовательная [Seriya leksiko-slovoobrazovatelnaya], вып. I-X, Москва - Warszawa - Минск - Братислава 1988-2012.

Програма (1909), Михальчук К., Тимченко Є. [Mykhalchuk K., Tymchenko Ye.], Програма для збирання діалектичних одмін української мови [Prohrama dlia zbyrannia dialektychnykh odmin ukrainskoi movy], Київ.

Програма (1910), Михальчук К., Кримський А. [Mikhalchuk K., Krimskij A.], Програма для собирания особенностей малоруських говоров [Programa dlya sobiraniya osobennostej maloruskix govorov], С.-Петербург.

Програма (1949), Ларін Б.О. [Larin В.О.], Програма для збирання матеріалів до Діалектологічного атласа української мови [Prohrama dlia zbyrannia materialiv do Dialektolohichnoho atlasa ukrainskoi movy], Київ.

Скляренко В.Г. [Skliarenko V.H.] (1983), Нариси з історичної акиентологї̈ української мови [Narysy z istorychnoi aktsentolohii ukrainskoi movy], Київ.

AGB, Atlas gwar bojkowskich, т. I-VII., pod kier. J. Riegera, Wrocław - Warszawa - Kraków Gdańsk - Łódź 1980-1991.

Rieger J. (1996), A Lexical Atlas of the Hutsul Dialects of the Ukrainian Language, compiled and edited from the fieldnotes of Jan Janów and his students by Janusz A. Rieger, Warszawa.

Smułkowa E. (2002), Białoruś i pogranicza, Warszawa.

Stieber Z. (1956-1964), Atlas językowy dawnej Łemkowszczyzny, z. I-VII, Łódź. 